\title{
Correction to: The effect of vitamin $D$ and magnesium supplementation on the mental health status of attention-deficit hyperactive children: a randomized controlled trial
}

\author{
Mostafa Hemamy ${ }^{1}$, Naseh Pahlavani ${ }^{2,3}$, Alireza Amanollahi', Sheikh Mohammed Shriful Islam5 , Jenna McVicar ${ }^{5}$, \\ Gholamreza Askari ${ }^{* *}$ and Mahsa Malekahmadi ${ }^{1,6^{*}}$
}

\section{Correction to: BMC Pediatr 21, 178 (2021) \\ https://doi.org/10.1186/s12887-021-02631-1}

Following the publication of the original article [1], the authors found out that affiliations were assigned incorrectly. Corrected information is provided in the author group section above and the affiliation section of this article.

The original article has been corrected.
Published online: 12 May 2021

\section{Reference}

1. Hemamy M, Pahlavani N, Amanollahi A, et al. The effect of vitamin D and magnesium supplementation on the mental health status of attentiondeficit hyperactive children: a randomized controlled trial. BMC Pediatr. 2021;21(1):178. https://doi.org/10.1186/s12887-021-02631-1.

\section{Author details}

${ }^{1}$ Department of Community Nutrition, School of Nutrition and Food Sciences, Isfahan University of Medical Sciences, Isfahan, Iran. ${ }^{2}$ Social Development and Health Promotion Research Center, Gonabad University of Medical Sciences, Gonabad, Iran. ${ }^{3}$ Cellular and Molecular Research Center, Research Institute for Health Development, Kurdistan University of Medical Sciences, Sanandaj, Iran. ${ }^{4}$ Department of Epidemiology, School of Public Health and Safety, Shahid Beheshti University of Medical Sciences, Tehran, Iran. ${ }^{5}$ Institute for Physical Activity and Nutrition (IPAN), School of Exercise and Nutrition Sciences, Deakin University, Melbourne, Australia. ${ }^{6}$ Research Center for Gastroenterology and Liver Disease, Shahid Beheshti University of Medical Sciences, Tehran, Iran. 021-02631-1.

*Correspondence: askari@mui.ac.ir; malekahamdimahsa@gmail.com 1 Department of Community Nutrition, School of Nutrition and Food Sciences, Isfahan University of Medical Sciences, Isfahan, Iran

Full list of author information is available at the end of the article

(c) The Author(s). 2021 Open Access This article is licensed under a Creative Commons Attribution 4.0 International License, which permits use, sharing, adaptation, distribution and reproduction in any medium or format, as long as you give appropriate credit to the original author(s) and the source, provide a link to the Creative Commons licence, and indicate if changes were made. The images or other third party material in this article are included in the article's Creative Commons licence, unless indicated otherwise in a credit line to the material. If material is not included in the article's Creative Commons licence and your intended use is not permitted by statutory regulation or exceeds the permitted use, you will need to obtain permission directly from the copyright holder. To view a copy of this licence, visit http://creativecommons.org/licenses/by/4.0/ The Creative Commons Public Domain Dedication waiver (http://creativecommons.org/publicdomain/zero/1.0/) applies to the data made available in this article, unless otherwise stated in a credit line to the data. 